\title{
CREDIT IN THE ISLAMIC ECONOMIC PERSPECTIVE
}

\author{
Ahmad Wahyu Hidayat \\ UIN Sunan Kalijaga Yogyakarta \\ Email: ahmadwahyuhidayat95@gmail.com \\ A. Zamakhsyari Baharuddin \\ STAIN Majene West Sulawesi \\ Email: ansamad90@gmail.com \\ Muhammad Iqbal Fasa \\ Doctoral Candidate at UIN Sunan Kalijaga Yogyakarta \\ Email: muhammadiqbalfasa@ymail.com
}

\begin{abstract}
In social life, Muslims often encounter forms muamalah. One of the forms muamalah is buying and selling. Sale and purchase allowed by Islam is the buying and selling that does not contain elements of usury, maysir, and gharar. Each transaction is considered valid if it meets the requirements and get along well defined purchase and in accordance to Islamic law. Credit according to Islamic terms is the right to receive payment or obligation to make payment at the time requested, or in the future, because the delivery of the goods now. While the credit sharia financing is known for providing money or bills based on agreements between the company and other parties, which require the other party to restore the funding after a certain period of time in exchange for results.This paper describes about definition, functions, objectives, elements and other types of credit, determine mortgage interest and the goodness and badness of credit, credit in Islamic economic perspective. Islam regards the practice of buying and selling as a legitimate practice and have a great maqasid for sustaining human life, maintain the property, life, lineage, intellect and serenity spiritual and physical. There are also practices in the name of selling but the fact is forbidden usury. The development of the understanding of this practice is consuming a variety of studies, so there is that to allow and forbid. Nothing justifies and forbid the sale and purchase with accounts payable, which is currently known by the term credit.
\end{abstract}

Keywords: Credit, Islamic Economic Perspective

\begin{abstract}
Abstrak
Dalam kehidupan sosial, umat Islam sering mengalami bentuk-bentuk muamalah. Salah satu bentuk muamalah adalah jual beli. Jual beli yang diizinkan oleh Islam adalah jual beli yang tidak mengandung unsur riba, maysir, dan gharar. Setiap transaksi dianggap sah jika memenuhi persyaratan dan mendapatkan pembelian yang didefinisikan dengan baik dan sesuai dengan hukum Islam. Kredit menurut ketentuan Islam adalah hak untuk menerima pembayaran atau kewajiban untuk melakukan pembayaran pada saat diminta, atau di masa depan, karena pengiriman barang sekarang. Sedangkan pembiayaan kredit syariah dikenal menyediakan
\end{abstract}


uang atau tagihan berdasarkan kesepakatan antara perusahaan dan pihak lain, yang mengharuskan pihak lain untuk mengembalikan dana setelah jangka waktu tertentu sebagai imbalan atas hasil. Makalah ini menjelaskan tentang pengerian, fungsi, tujuan, elemen dan jenis kredit lainnya, cara menentukan bunga kredit, kebaikan dan keburukan kredit, dan kredit dalam perspektif ekonomi Islam? Islam menganggap praktik membeli dan menjual sebagai praktik yang sah dan memiliki maqasid yang hebat untuk mempertahankan kehidupan manusia, memelihara properti, kehidupan, garis keturunan, kecerdasan dan ketenangan spiritual dan fisik. Ada juga praktik dalam nama jual tetapi faktanya adalah dilarang riba. Perkembangan pemahaman praktik ini adalah mengonsumsi berbagai studi, sehingga ada yang boleh dan dilarang. Tidak ada yang membenarkan dan melarang penjualan dan pembelian dengan hutang, yang saat ini dikenal dengan istilah kredit.

\section{Kata Kunci : Kredit, Perspektif Ekonomi Islam \\ INDTRODUCTION}

The development of Islamic economic thought have started since Muhammad as a messenger (messenger of God). Prophet issued a number of policies relating to the various issues related to the conduct of public life, in addition to the legal issues, politics, as well as commercial or economic problems. Economic issues of concern to the people of the Prophet, because of economic problems is a pillar of faith that must be observed by the whole community.

As narrated by Muslim, the Messenger of Allah said, "Poverty brings people to disbelief". Efforts to reduce poverty are part of the social policies issued by the Prophet. Furthermore, the Prophet policies into guidelines by the successor of Abu Bakr, Umar, Uthman, and Ali ibn Abi Talib in deciding economic problems.

Nevertheless, the Qur'an and the Hadith is used as the basis of economic theory by the caliphs also used by his followers in managing the country's economic life. The development of Islamic economic thought at the time of the Prophet Muhammad has not developed, it is because people at that time directly to practice and see if the issue can be asked directly to the Prophet.

In a world increasingly modern as today, the need for an item in the infinite human life increasingly requires every individual should have it. Consumptive patterns of modern society as it is today is not matched with a per capita income of each individual. Therefore, banks in Indonesia and other countries, especially conventional banks and other financial institutions (non-banks) provide 
convenience to every element of society in the form of financing the purchase of goods and borrowing money in the form of credits.

When we talk about credit problems, or problems selling it can not be separated from the term riba or interest benefit from the results of financing in the form of purchases of goods and borrowing money in the form of loans made banks and other financial institutions. The overall picture of the Qur'an in surah Al-Baqarah 275 describes usury, which reads:

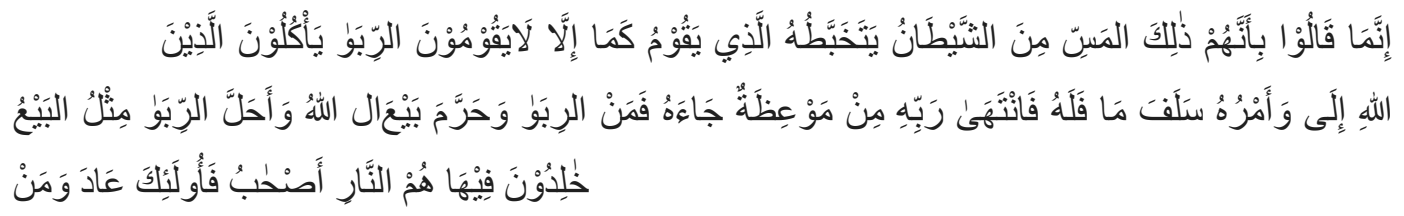

This means: "People who Eat (take) usury can not stand but as stands one whom possessed devil because the (pressure) insanity. Their circumstances were such that, is because they say (argued), Truly buying and selling the same as usury, And Allah has permitted trading and forbidden usury. people who have admonition from his Lord and stops (from taking usury), then for him what he has taken in advance (before coming ban); and affairs (up) to Allah. The returnees (usury), So they are the dwellers of Hell; they will abide therein".(QS. AlBaqarah, 2: 275)

Proposition above is the argument of the texts on which to base the muamalah problem of this type, which in essence that Islam prohibits any acts flowering of money (riba). But do not assume that Islam forbids lending, essentially Islam allows credit in the world trade. Especially in societies that embrace today's modern economic system, requires credit and loans.

According to Law 10 of 1998 states that the loan is to provide cash or the equivalent, based on agreements between bank lending and other parties who require the borrower to repay the debt after a certain watu with interest. If someone uses a credit, then he will be charged interest bill.

Sales by payment in cash and credit is one concrete example of the development of the sale and purchase transaction has been done by mirko and macro businesses. At this time, this fact can not be avoided because the 
businessmen or Indonesian companies already implementing a sales system in this way. Of goods Automotive, Electronics, furniture to clothes and fashion at this moment implement sales with two option price in cash and credit mechanisms. Based on the above author will discuss the credit in the perspective of Islamic economics.

\section{DEFINIITION OF CREDIT}

Credit (sell or buy on credit / installment) in Arabic is called Bai'bit Taqsith whose meaning according to the terms of Shariah, is to sell something to the payments in installments with a particular installment, at certain times, and more expensive than cash payments / cash. ${ }^{1}$ Credit comes from the Greek "credere" which means belief in the truth in everyday practice. ${ }^{2}$

Credit is also derived from the Italian word, meaning cedere trust. Trust within the meaning of credit is between the giver and the recipient of the credit. Credit is the provision of achievement (eg : money and goods) to reply to the achievements that will happen in the future. ${ }^{3}$ According to the terms Kerdit is something that is paid gradually both the buying and selling as well as the lending and borrowing. For example, a buy to a dealer with an advance of $10 \%$ and the balance is paid gradually over the years and paid only once a month. Credit can also occur in people who borrow money from a bank or a cooperative, then the loan is paid gradually, there is paid daily, weekly, and some are paid once a month.

According to Law No. 7 of 1992 on the main points of Banking, definition of credit is the provision of cash or the equivalent, based on the consent or loans between banks and other parties that requires the borrower to repay the debt after a certain period with the amount of interest, rewards, or profit sharing. Banks that

${ }^{1}$ Syarah Majalah al-Ahkam, no 157, vol III/110, Majallah asy-Syari'ah wad Dirasah AlIslamiyah, Fak Syari'ah, Kuwait University, edisi VII, Sya'ban 1407, hlm. 140, Al-Maurid, hal. 354, Lisanul 'Arab, vol VII/377-378, melalui artikel di situs Eramuslim.com.

${ }^{2}$ Hendi Suhendi, Fiqh Muamalah (Jakarta: Rajawali, 2010), hlm. 299

${ }^{3}$ Rachman F dan Maya F. Manajemen Perkreditan Bank Umum: Teori, Masalah Kebijakan dan Aplikasinya, (Bandung: Alfabeta, 2013), hlm. 15. 
berpedomannya is to obtain the highest result of the money loaned without questioning the use of credit given. ${ }^{4}$

In this matter, Raymond P. Kent in his book Money and Banking said that "Credit is the right to receive a payment or obligation to make the payments and the obligation to make payment on demand, or pda time to come, because the delivery of goods now". ${ }^{5}$ According to Mulyadi credit sales are credit sales carried out by the company by sending the goods in accordance with orders received from buyers and for a certain period the company has receivables from the buyer. ${ }^{6}$ Credit according to terms is the right to receive payment or obligation to make payment at the time requested, or in the future, because the delivery of the goods now. While the credit sharia financing is known for providing money or bills based on agreements between the company and other parties, which require the other party to restore the funding after a certain period of time in exchange for results. $^{7}$

In broad terms, the financial credit is provided by a third-lender, seller, or a shareholder / owner to another party borrower, buyer, or a business enterprise. ${ }^{8}$ Sulaiman bin Turkey defines credit purchase is a sale purchase where the goods handed over in advance, while payments were made some time later by deal. ${ }^{9}$ In bukunnya Sahruwardi K Lubis argued that the definition of credit is a purchase made on something goods payment price of these goods is done gradually in accordance with the agreed payment phases of both parties that the seller or buyer. $^{10}$

${ }^{4}$ O.P. Simorangkir, Pengantar Lembaga Keuangan Bank Dan Non Bank, Cet. II (Bogor: Ghalia, 2004), hlm. 101.

${ }^{5}$ Thomas Suyatno, dkk, "Dasar-dasar perkreditan”, (Jakarta: PT.Gramedia Pustaka Utama, 2007), hlm.12.

${ }^{6}$ Uci Fitriani, Makmur, Andi Afrizal, Pengaruh Sistem Penjualan Kredit Di Pt. Surya Putera Sumatera Raya Ii Pasir Putih Pasir Pengaraian Terhadap Penarikan Sepeda Motor Yamaha, jurnal Prodi Manajemen, Fakultas Ekonomi, Universitas Pasir Pengaraian, hlm. 1-17

${ }^{7}$ Ahmad Gozali, Serba-Serbi Kredit Syariah: Jangan Ada Bunga Diantara Kita, (Jakarta: PT. Elex Media Koputindo, 2005), hlm.135

${ }^{8}$ Zubair Hasan, Credit creation and control: an unresolved issue in Islamic banking, International Journal of Islamic and Middle Eastern Finance and Management, Vol. 1. Iss 1, 2008. hlm. 69-81.

${ }^{9}$ Imam Mustofa,Fiqh Muamalah kontemporer, (Jakarta: Rajawali pers, 2016), hlm. 49

${ }^{10}$ Sahruwardi K Lubis, Hukum Ekonomi Islam, (Jakarta: Sinar Grafika, 2000), hlm. 142 
Credit in another sense also means the provision of money or bills that can be likened to it, based on the approval of the borrowing and lending between banks and other parties who require the loan to pay off debt after a period of time with the amount of interest, imbalan or profit sharing. ${ }^{11}$

According Muchdarsyah credit is the provision of an accomplishment by any other party and that achievement will be returned at a certain time to come accompanied by a counter accomplishments of interest. ${ }^{12}$ Bank credit is aimed at helping the availability of funds to finance the activities of the national production, storage of material, sales credit financing, transport of goods and trade activities. The role of credit is quite dominant in a country that is developing in order to develop the economic potential. ${ }^{13}$

Based on the description above can be concluded that the loan is to buy an item given the trust to pay in installments or in installments within a period agreed between the seller and the buyer. Where should provide additional price on the goods delayed payment of goods which are paid directly (cash). But forbidden for debtors to delay its obligations in paying installments.

\section{A. Function and Purpose of Credit}

Meanwhile, according to Muhammad Muslehuddin main function of credit is to give the possibility to an entrepreneur to start a business on a large scale (large-scale). Credits are used to move the existing capital and enable the commencement of production prior to the development of demand, namely to increase the sale of products to consumers. ${ }^{14}$

Credit function for the community, among others:

1. A motivator and a dynamic increase in trade and economic activities.

2. Expanding employment for the community

11 Miftah Idris, Perjanjian Kredit Perbankan Konvensional dan Akad Pembiayaan Perbankan Syariah: Suatu Tinjauan Deskriptif Dalam Hukum Di Indonesia, Jurnal Komunikasi Hukum Universitas Pendidikan Ganesha Singaraja, Volume 1 Nomor 1 Pebruari 2015, hlm. 24-42.

12 Muchdarsyah Sinungan, Dasar-dasar dan Tehnik Managemen Kredit, cet. 7 (Jakarta: Bina Aksara, 2003), hlm. 112.

${ }^{13}$ Andi Nursyahriana, Michael Hadjat, Irsan Tricahyadinata, Analisis Faktor Penyebab Terjadinya Kredit Macet, Jurnal FORUM EKONOMI Volume 19, No. 1 2017, hlm. 1-14.

${ }^{14}$ Muhammad Muslehuddin, Sistem Perbankan Dalam Islam, (Jakarta: PT Rineka Cipta, 2004) cet ke-3, hlm. 36. 
3. Facilitate the flow of goods and cash flow

4. Improving international relations

5. Increase the productivity of existing funds

6. Improve the usability of goods

7. Boost the excitement of trying to society

8. Enlarge the company's capital

9. Increase income per capita community

10. Changing the way people think to be more economical.

In the book the law of the credit agreement. Harun Hazniel argued that the purpose of the credit is as follows: ${ }^{15}$

1. Small communities alleviate the credit system in terms of acquiring the goods in a lawful manner. It is taken for financial reasons that are used for a variety of other needs, while the desired item can be obtained quickly.

2. To maintain a balance between those capable people who can not afford.

From the above explanation credit goal in the Islamic law provides the opportunity and convenience for someone who needs an item while he has no money to pay for them in cash. So in a way this is a credit to be able to have the goods.

Interest loans among others are:

1. Earned income from lending banks

2. Utilizing and producing existing funds

3. Conducting Operations of banks

4. Meet the credit demand of society

5. Streamlining payment traffic

6. Adding to the company's working capital

7. Increase the income and welfare of the community.

\footnotetext{
${ }^{15}$ Hazniel Harun, Hukum Perjanjian Kredit, (Yogyakarta: Tritura, 1989), hlm. 12.
} 


\section{B. Elements of Credit}

1. Confidence, that confidence of the lender that his achievements were given either in the form of money, goods, or services, would actually return preformance receipt of a certain period in the future.

2. Time, which is a period that separates administration with contra achievement to be received in the future.

3. Degree of risk, which is a level of risk that will be faced as a result of the existence of a period of time that separates between the awarding of performance and the achievement that will be received in the future.

4. Achievement, or the object of credit should not be given in the form of money, but also to the form of goods or services. However, due to today's modern life is based on money, the credit transactions that would involve money that is often encountered in lending practices. ${ }^{16}$

All the scholars have agreed on the issue of allowing the buying and selling credits. In sale and purchase of credit, there are several conditions that affect the validity of the contract:

1. Each other's approval.

2. The person doing the contract is a free man.

3. There is a full property rights. ${ }^{17}$

\section{General Conditions of Credit Interest}

In general, the determination of lending to distinguish between a loan with other loans are: ${ }^{18}$

\section{Credit Period}

In general, the credit period is a reflection of credit risk that may arise. The longer the loan period the higher the risk that may arise, the bank will charge a higher interest rate compared to short-term credit.

\section{Credit Guarantees Quality}

${ }^{16}$ Idris Yahaya Adamu, Ahmad Khilmy bin Abdul Rahim, Abu Bakar Hamed, Access to Credits and Indebtedness: Islamic Perspective, International Journal of Accounting, Finance and Risk Management, 2016; 1(1), hlm. 46-52.

${ }^{17}$ Saleh Al-Fauzan, Fiqh Sehari-Hari, (Jakarta: Gema Insani, 2006), hlm. 94.

18 Thomas suyatno,dkk, Dasar-Dasar Perkreditan" (Jakarta: PT.Gramedia pustaka utama, 2007), hlm. 101 . 
Credit guarantees is one very important factor in giving consideration as to how the amount of interest that will be charged to an individual customer / company. When customers provide a credit guarantee which has a very high quality that is easily liquidated, its value does not decrease, very easily traded.

\section{Company reputation}

In general, the credit recipient firms can be divided into three major groups, namely:
a. Companies (MNC'S, JV, etc.)
b. State-Owned Company (State-Owned Enterprises / BUMN)
c. PerusahaanMenengah (Wholesale, Import and Export)
d. Small firms (individual entrepreneurs, and others)

The Bank will determine the lowest interest rate on companies that have a very good credit-rating. In contrast, the companies that have credit-rating is not good, the bank will charge a higher interest rate.

\section{Competitive Products}

Very high competitive carries a high risk for the company, which in turn will affect the risk of bank loans to the company. So the bank will determine the higher lending to companies.

\section{Good relationship}

What is meant by good relationships, how bank notes (hisrotorial focard) from the relationship. If a company has a long relationship with the bank with very satisfactory provisions for banks.

\section{Third Party Assurance}

The presence of a third party guarantee sufficient Bonafide terms of bank ratings will affect the determination of bankyang interest charged by the bank. Third party guarantee, granted by banks and corporations by banks. Diberikn third party assurance by the company in the form bankd an acceptance can reduce credit risk.

\section{CREDIT IN ISLAM ECONOMIC PERSPECTIVE}

In Islamic economics, credit is known as financing, while what is meant by financing is provision or bills that can be equated and this is based on an 
agreement or agreement between the bank and another party that requires the financed party to return the money or bill after a certain period of time and reward or mutually agreed upon results. The emergence of Islamic economics resulted from a long search for alternative economic systems aimed at the world order with ontological and epistemological sources of law (ie, the Qur'an and Sunnah) that would serve as the framework of this world order value system. ${ }^{19}$

By Anwar Iqbal Qureshi, objective facts that Islam prohibits any flowering of money. This does not mean that Islam forbids lending Qureshi because according to modern economic system will not be smoothly without credit and loans. ${ }^{20}$ Islamic law regulate human life as a whole, covering all sorts of aspects, and the relationship between man and God set in the field of worship and man's relationship with his neighbor mu'amalat set in fields in the broadest sense, either individually or as a general nature, such as marriage, inheritance, legal agreements, public administration, relations between countries, penal law, justice and so on. ${ }^{21}$

In that case, Qureshi condemned usury (interest and usury) and suggest mechanisms for sharing profit and loss account as an alternative method. According to him, the business is legal in Islam kopartnership where one partner capital suppliers be entitled to revenue given that she capital supply without taking an active part in the concern. ${ }^{22}$ As it is known that the laws relating to social life in the community regarding the material and the rights and Completion of old disputes such as the sale and purchase agreement, lease, debts, liens, grants, etc. legal group is called the Mu'amalat Law. ${ }^{23}$

\footnotetext{
${ }^{19}$ Daud A. Mustafa, Hashir A. Abdulsalam and Jibrail B. Yusuf, Islamic Economics and the Relevance of Al-Qawa'id Al-Fiqhiyyah, Jurnal SAGE Open, Vol.1. Issue.1, October-December 2016, hlm1-11.

${ }^{20}$ Anwar Iqbal Qureshi, Islam dan Teori Pembungaan Uang, (Jakarta: Tintamas, 1985), hlm. 130.

21 Azharsyah Ibrahim, Kartu Kredit dalam Hukum Syariah: Kajian terhadap Akad dan Persyaratannya, Jurnal al-Mu'ashirah, Vol. 7, No. 1, 2010, hlm, 89-106.

${ }^{22}$ Z. Hafsa ORHAN ASTRÖM, Credit-Related Practices of Islamic Banks in Comparison with Theory: Case Study of Turkey, International Journal of Islamic Economics and Finance Studies, 2015, Year:1, Volume:1, Number: 2, hlm. 39-60.

${ }^{23}$ Ahmad Azhar Basjir, Asas-asas Hukum Mu'amalat, (Yogyakarta: Perpustakaan Fakultas Hukum UII, 2000), hlm 5.
} 
The mu'amalat of the law relating to the sale and debts are credit issue, here need to explain the presence of some definition of credit. Credit comes from the Greek "Credere" which means confidence (trust or fait), therefore the basis of the credit is trust. Credit by epictimologi believe in people getting credit. Then the words turned into a loan credit (loans granted creditor to the debtor) on the basis of trust that at any time the loan will be returned in the hope of certain benefits. ${ }^{24}$

The importance of an efficient credit risk management invited many parties, especially researchers, regulators, and the bank's management to investigate the determinants of credit risk in the banking system. This will help them to understand and propose the framework of a comprehensive credit risk management. Most research suggests that there are two strands of the literature on the factors that drive credit risk. The most popular strand indicates that the credit risk is driven by some bank-specific variables (BSV) and the second strand argues that macroeconomic factors greatly affect the banks' credit risk. ${ }^{25}$

In any modern economy, one would find that happy bank depositors put their capital at risk for the promise of higher returns. Also, people will find banks willing to produce the variable returns on most, if not all, of their assets to increase their expected income. So where financial intermediaries are free to choose a mix of selection of fixed and variable income, and also for their loan commitments, competitive pressures will provide economic agents who refuse the opportunity interest in participating in such transactions Islamic Economist characterizes as "the distribution of gains and losses". ${ }^{26}$

In the Banking Act Chapter 1 Article 1 of Law number 10 principal banks in 1998 gave the following formula:

${ }^{24}$ Ahmad Muhyiddin, Etika Bisnis Perbankan, (Yogyakarta: CV Mulia Sari, 1994), hlm 99.

${ }^{25}$ Faridah Najuna Mismana, Ishaq Bhatti, Weifang Lou, Syamsyul Samsudin, Nor Hadaliza Abd Rahman, Islamic Banks Credit Risk: A Panel study, Procedia Economics and Finance, Vol. 31. Issue. 1. 2015, hlm. 75-82.

26 Timur Kuran, Islamic Economics and the Islamic Subeconomy, Journal of Economic Perspectives, American Economic Association, Volume 9, Number 4, Fall 1995, Pages 155-173. 
Credit is the provision of cash or the equivalent, based on the approval or the borrowing and lending between banks and other parties who require the borrower to repay the debt after a certain period of time with interest. ${ }^{27}$

In Islamic economics recognized credits with financing, while the meaning of the financing is the provision or equivalent claims and is based on agreements between the bank and other parties who require the financed party to return the money or the charges after a certain period of time and reward or for the results of which have been agreed.

There are some Islamic Banking products are known in Islamic Economics are: ${ }^{28}$

1. al-Musharaka

Is a partnership contract between two parties or more for a particular business and each - each party contributes funds and the benefits and risks will be shared in accordance with the agreement.

2. al- Mudharabah

Is a contract of business cooperation between the two parties and the provisions of the first party to provide all the capital, while the other party to become a manager and business profits are divided according to the agreement set forth in the contract. Mudharobah generally divided into two types: mudharobah mutlaqah and mudharobah muqayyadah. While the mudaraba mudaraba muqayyadah is the opposite of mutlaqah. The mudhorib limited to specifying the type of effort, time or place of business. These restrictions are often reflects the general tendency shahibul maal in entering the business world types.

3. al-Murabahah

Is selling goods at the original price and the additional benefits agreed with the seller must notify the conditions that he bought the product price and determining a level of profit as enhancements.

${ }^{27}$ M. Faisal Abdullah, Managemen Perbankan, Teknik Analisis Kinerja Keuangan Bank, (Malang: UMM press, 2003), hlm. 163.

${ }_{28}$ Muhamad Safi'i Antonio, Bank Syariah Dari Teori ke Praktek, (Jakarta: Gema Insani Press, 2001), hlm. 97. 


\section{As- Bai Salam}

Are ordering goods with the requirements determined and submitted later in the day, while the payment is made before the goods are received.

5. Bai Al-istishna

Is a contract of sale between the buyer and the manufacturer items through the order, the manufacturer is obliged to fulfill the order items according buyer and the agreed specifications.

6. al-Ijarah

Is a contract of transfer of rights to the goods or services through lease payments not followed by the transfer of ownership of the goods themselves.

\section{Qard Al-Hasan}

Is a contract that is devoted to the loan of treasures that are scalable and can be charged again and is help each contract and is not a commercial transaction. $^{29}$ One of them lending cash to virtue (Qard Al-Hasan) without charge except for an administration fee in the form of all the costs necessary for the validity of the debt agreement, such as stamp duty, notary deed duties, customs feasibility studies and so on. Of lending Qardhul Al Hasan, the Bank will receive administrative expenses. ${ }^{30}$ In the form of implementation in the field, in addition to providing the capital needed to buy a small community capital goods (work tools), operating working capital and other factors that are needed to build a small business unit, Islamic banks should ideally also have to provide assistance such aspects menajerial financial marketing and to facilitate the production even more efficient marketing network profitable small and medium businesses.

\section{A. Sale And Purchase of Credits Is Not Allowed}

${ }^{29}$ Merza Gamal, Aktivitas Ekonomi Syari'ah, (Pekanbaru: UNRI Press, 2004), hlm.70.

${ }^{30}$ Amir Machmud, Dkk, Bank Syariah Teori, Kebijakan, Dan Studi Empiris Di Indonesia, (Bandung: PT Glora Aksara Pratama, 2010), hlm. 29. 
Among those who think so clerical 'contemporary is Imam Al-Albani which he put in a lot of his books, such as Lineage ahadith Ash Shohihah 5 / 419427 also his disciples Shaikh Salim al Hilali in Mausu'ah Al Manahi Ash Syar'iyah 2 / 221 and the other also. They berhujjah with some of the following proposition:

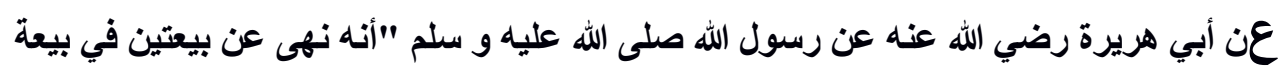

From Abu Huroiroh of Rosululloh bahwasannya he forbade two sale and purchase transactions in the purchase transaction. "31

In other history with lafadl: "Whoever performs two sale and purchase transactions in the sale and purchase transactions, then he should take the lowest price, otherwise it will fall on usury." 32

Interpretation from the Messenger SAW ban "Two sale and purchase transactions in one transaction" is a statement of a seller or buyer: "This good if it costs this much cash credit whereas if it costs that much."

Regarding credit sales with the addition of price, Sheikh Muhammad Nasiruddin al-Albani also says:

"Whoever sells the two (price) sales in a single sale, then for him (the price, -pent) the least or (if not, then the higher the price is, -pent) riba" 33

Imam Ibn Qutaibah also explain the (information) is, he said in "Gharib alHadith (I / 18):" Among the buying and selling is forbidden (is) two terms (price) in one sale, that (for example) a person buying goods worth two denarii if the

\footnotetext{
${ }^{31}$ HR. At-Tirmizi, Sunan Tirmizi, (Semarang: Toha Putra, tth), Nomor Hadis 1331.

${ }^{32}$ HR. Abu Dawud 3461, Hakim 2/45 dengan sanad hasan.

${ }^{33}$ Diriwayatkan oleh Ibnu Abi Syaibah di dalam "Al-Mushannaf (VI/120/502)", Abu Daud dari Ibnu Abi Syaibah (no. 3461), Ibnu Hibban di dalam "Shahihnya (1110)", Al-Hakim (II/45), dan Al-Baihaqi (V/343) kesemuanya meriwayatkan bawha telah becerita kepada kami Ibnu Abi Zaidah dari Muhammad bin Amir dari Abu Salamah dari Abu Hurairah secara marfu, sanadnya hasan, bahkan telah dishahihkan oleh Al-Hakim, dan disepakati oleh Adz-Dzahabi, juga oleh Ibnu Hazm di dalam "Al-Muhalla (IX/16). Juga diriwayatkan oleh An-Nasa'i (VII/296, cetakan baru), At-Tirmidzi (I/232), dia menshahihkannya, Ibnul Jarud (286), Ibnu Hibban (1109), Al-Baghawi di dalam "Syarh As-Sunnah (VIII/142/211)", ia juga menshahihkannya, Ahmad (II/342, 375, 503) dan Al-Baihaqi dari beberapa jalan dari Muhammad bin Amr dengan lafazh : "Beliau melarang dua (harga) penjualan di dalam satu penjualan" diambil dari
} http://jacksite.wordpress.com/. 
expiration of two months, and for thirty denarii if the expiration of three months. That is the meaning of "two (price) sales in one sale." ${ }^{\text {34 }}$

And also narrated by Imam Ahmad (I / 393), and this is also a history of Ibn Hibban (1112) (Ibn Mas'ud, -pent) with the wording: "Not worth two contract of sale in the contract of sale (according to the wording of Ibn Hibban: It is not lawful two sale and purchase agreement) and indeed the Prophet sallallaahu 'alaihi wa sallam has said: "Allah has cursed the eater (riba) eater usury are people who take it, although not eat, disclosed to eat because eating is the usefulness of the greatest of usury and because usury was generally around food. Giver of usury is one who gives usury to those who take it, even though the take was not eating, ". By sanadnya also authentic.

Sufyan al-Thawri, saying that, if you say, "I sell to you in cash (for) something, and with cash (for) so and so", then the buyer took it away, then he is entitled to choose between the two (the price) sales before, during yet occurred buying and selling decisions on one price. And if there has been a sale like this, then it adala dibenci.Itulah "two sales in one sale", and it was rejected and forbidden. So if you find your things intact, you can take the lowest price and a longer time. ${ }^{35}$

Most fuqoha 'also does not allow the sale and purchase on credit, they argued that the price increase related to the problem of time, and it is no different with usury. Another opinion also said that raising the price above which is actually closer to usury nasi'ah that extra price, then it is clearly prohibited Allah. ${ }^{36}$

They argue that any loan that diembel embroider in addition, it is usury. Thus, standardization within each business is located on its objectives. For example: Someone needs a bike, then came to a trader who does not have it, he said, "I need a bike that such and such". So traders go and buy it, then sell to him on credit at prices much. Can not be denied, that this is a form of deception,

\footnotetext{
${ }^{34}$ Adanan Murroh Nasution, Jual Beli Kredit Ditinjau Dari Persefektif Hukum Islam, Jurnal Yurisprudentia Volume 2 Nomor 2 Desember 2016, hlm. 19-34

${ }^{35}$ Diriwayatkan oleh Abdur Razaq (14632) dari Sufyan Ats-Tsauri.

${ }^{36}$ Abu Umar Faruq Ahmad dan M. Kabir Hassan, Riba And Islamic Banking, Journal of Islamic Economics, Banking and Finance, Vol.1, No.1 tahun 2007. hlm, 1-33.
} 
because the traders want to buy it just because the demand and not buy it for her out of pity for him but for the sake of gain, as if he lent it costs to people as usury. $^{37}$

\section{B. Sale and Purchase of Credits Allowed}

Credit conducted directly between the owner of the goods to the buyer is a commercial transaction which is permissible in the Shari'ah. Credit contract law remains valid, even if the purchase price of the loan is greater than the purchase price by way of cash. This is the opinion of the extent of the knowledge I have, the most powerful, and this opinion is the opinion of most scholars. As for the opinion of jurisprudents allow it jumhur like Hanafi, Shafi, Zaid bin Ali Al Muayyad Billah that the purchase for which payment is deferred and at no additional price from the seller because the suspension is legitimate, because they think the delay is the price, because they view of the general proposition that allow, and texts that forbid it does not exist, the most important is the addition of the suspension price is fair and reasonable prices, and the absence of coercion and dholim. ${ }^{38}$

According to Imam Mustafa purchase credits must meet a variety of the requirements established scholars. these requirements including: ${ }^{39}$

1. Sale and purchase on credit not to lead to riba

2. Seller is the perfect owner of goods sold

3. The goods are delivered to the buyer by the seller

4. Should the goods and the price is not the kind that allows the nasi'ah usury.

5. Prices in sale and purchase of credit is a loan (not paid in cash)

6. Goods are sold on credit delivered directly

7. Time payment is clear, according to the agreement

8. Payment should be done gradually, not to be paid directly.

${ }^{37}$ M. Ali Hasan, Masail Fiqhiyah: Zakat. Pajak, Asuransi dan Lembaga Keuangan (Jakarta: PT Raja Grafindo Persada, 2003), hlm. 172. hlm.169.

${ }_{38}$ M. Ali Hasan, Masail Fiqhiyah: Zakat. Pajak, Asuransi dan Lembaga Keuangan...,

${ }^{39}$ Imam Mustofa, Fiqh Muamalah kontemporer, (Jakarta: Rajawali pers, 2016), hlm.59 
The verse is also associated with credit problems is surah Al-Baqarah verse 282:

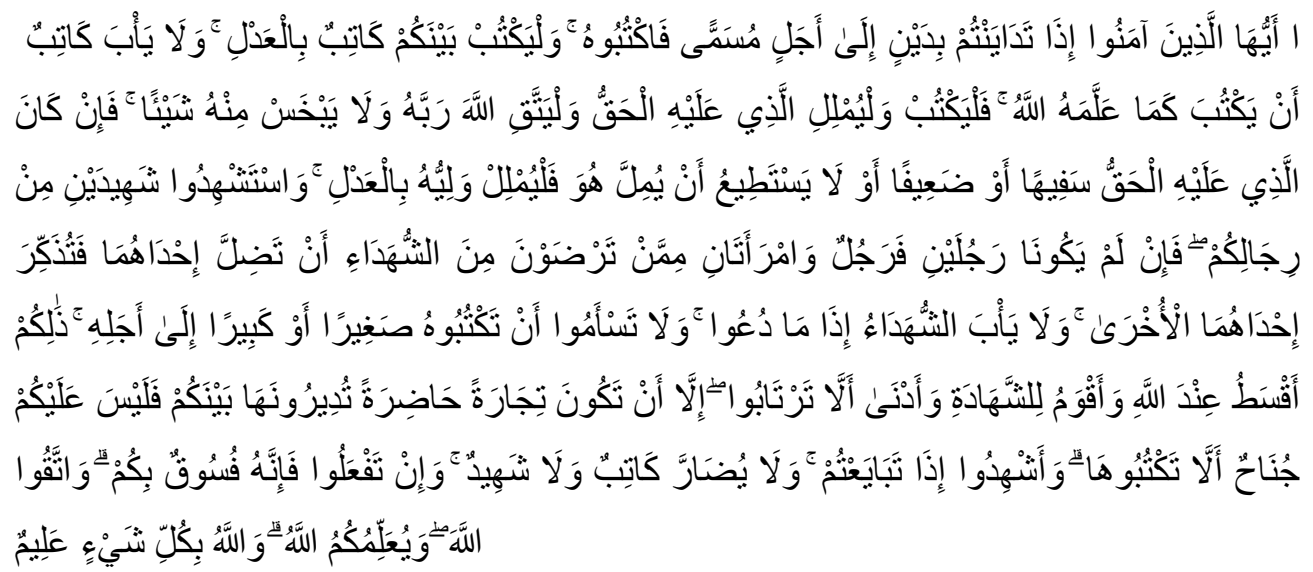

Meaning: $\mathrm{O}$ you who believe, if you are not in cash for the specified time, let you write it down. and let an author among you write it correctly and do not let the writer be reluctant to write it as God taught it, meka let him write, and let the debtor imitate (what will be written), and let him fear the God of his Lord, and let him not reduce the slightest bit than the debt. if the person who owes is someone who is weak or weak (the situation) or He himself is unable to imitate, then let his guardian honestly imitate and witness with two witnesses from men (among you). if there are no two men, then (may) a man and two women from witnesses who are ridhai, so that if someone forgets then one reminds him. let the witnesses not be reluctant (give testimony) when they are called; and don't be tired of writing the debt, both small and large until the time limit for paying it. that is so, more just by Allah and more affirming the witness and closer to not (raising) your doubts. (Write your mu'amalah), unless mu'amalah is the cash trade that you run between you, then there is no sin for you, (if) you did not write it. and witness if you are buying and selling; and don't let writers and witnesses find each other difficult. if you do (thus), then indeed it 
is wickedness in you. and fear Allah; God teaches you; and God knows everything. ${ }^{40}$

This verse is one proposition that justifies the practice of debt, while the credit agreement is a form of debt, with the generality of this verse is the basis allowing for credit. But the scholars as to allow the sale on credit, with provision for the seller and buyer follow the rules and the terms of validity as follows:

1. The price of goods is determined clearly and definitely known to the seller and buyer.

2. Payment of installments agreed by both parties and restricted payment due sehingg avoid parktik bai' gharar "business fraud".

3. The original price that has been agreed must not be raised due to the repayment exceeds the specified time, as it may fall on usury.

4. A seller may not exploit the needs of the buyers by raising prices too high exceeds the prevailing market price, in order to include the category bai' muththarr 'forced sale "that criticized the Prophet. ${ }^{41}$

Word of Allah Ta'ala:

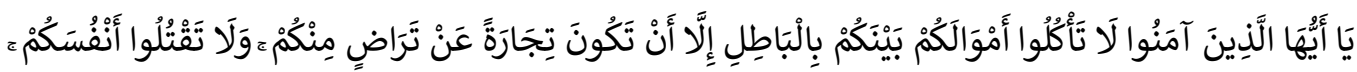

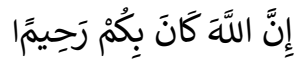

This means: "O those who believe, do not eat each other neighbor's property with a false way, except by way of commerce applicable to consensual among you. (QS. An Nisa 'verse 29)" 42

Generality of this paragraph includes the purchase in cash and credit, the credit while buying and selling is done by consensual then entered into what is permissible in this paragraph.

Hadith the Messenger Muhammad:

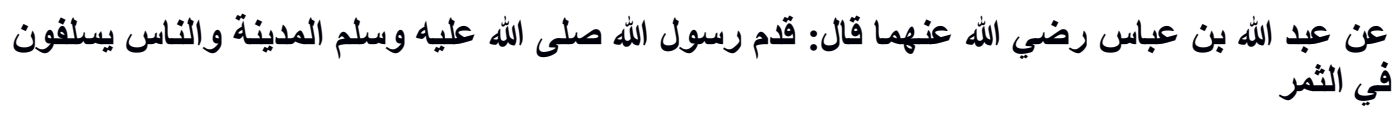

${ }^{40}$ Ibnu Abbas menjelaskan: “Ayat ini diturunkan berkaitan dengan jual beli As Salam (3) saja. ”Imam Al Qurthubi menerangkan: “Artinya, kebiasaan masyarakat Madinah melakukan jual beli salam adalah penyebab turunnya ayat ini, namun kemudian ayat ini berlaku untuk segala bentuk pinjam meminjam berdasarkan ijma' ulama'." Lihat Tafsir Al Qurthubi 3/243.

${ }^{41}$ Kutbuddin Aibak, Kajian fiqh kontemporer, (Yogyakarta: Teras, 2009), hlm. 216.

${ }^{42}$ Al-Qur'an dan Terjemahannya, (Jakarta: Al-Huda, 2005), hlm. 120 


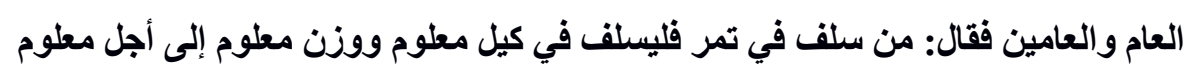

Meaning: "From Abdulloh bin Abbas said: "Rosululloh dartang to the city of Medina, and then the people of Medina buying and selling fruit by way of greeting within one or two years, then he said:" Whoever is selling greeting then let in a dose clear, clear up to the time scales are clear. " 43

Making the proposition of this hadeeth, that the Messenger allow buying and selling greeting as long as measures and weights as well as the repayment is clear, but usually in the buying and selling greeting the money to buy it less than if bought directly there goods. So as well as the sale and purchase of credit is the opposite, namely the goods first and money later though more than the price in cash.

Among the proposition there is also a hadith 'Aisha radi' anha:

"Praise be to Allaah The Prophet sallallaahu 'alaihi wa sallam buy food from a Jew with delayed payments and mortgaging of iron armor to him. ${ }^{\prime 44}$

\section{The Credit Proposals From Ijma ', Qiyas And Maslahat}

Most scholars 'claim that the permissibility of sale and purchase with a credit to the price difference is the consensus of the scholars'. Among them are:

\section{Shaykh al-Islam Ibn Taymiyyah Rahimahullah}

He was asked about a man who had a horse he purchased at a price of 180 dirhams, and then someone asked him the price of 300 dirhams in the period (payments) three months; whether it is lawful for him. He replied: "AlHamdulillah, When he bought it to be taken advantage or for it to trade then why not sell it until a time (with credit, -pent). But he must not take advantage of people who need but with a reasonable profit. Do it adds to (price) for its emergency (because she really needed it). As if he needed dirham then buy it (the

${ }^{43}$ Yonas Perwiratama, Sistem Jual-Beli Kredit Motor Di UD Sabar Motor Ditinjau Menurut Hukum Islam, (Fakultas Hukum Dan Fakultas Agama Islam, Universitas Muhammadiyah Surakarta, 2010), hlm. 1-14.

${ }^{44}$ Yonas Perwiratama, Sistem Jual-Beli Kredit Motor Di UD Sabar Motor Ditinjau Menurut Hukum Islam, (Fakultas Hukum Dan Fakultas Agama Islam, Universitas Muhammadiyah Surakarta, 2010), hlm. 1-14. 
horse, -pent.) For he was selling at the moment and he takes the price then this is makrooh according to the (opinion) the most zhohir of two scholarly opinion (1) ". Shaykh al-Islam Ibn Taymiyyah quotes bolehnya it is based on the Book, the Sunnah and al-Ijma. ${ }^{45}$

\section{Ibn Rusdy}

He gave the example of the sale and purchase of the credit system (bai'u aldeath) Such as: a sell goods at a specified price up to a certain period, then he bought it back for another until a certain period of another, or with a cash price. In connection with the change of time that the price may change. He bought it with cash (cash) before the time at a lower price than the actual price, or buy it at a price that was far from at that time and at a price that is greater than the actual. ${ }^{46}$

\section{Proposition qiyas}

As already passed that purchase these credits is figured by buying and selling greeting which explicitly allowed Rosululloh, because there are similarities, are equally delayed. just selling regards the goods are delayed, whereas the credit money is pending. Also in the sale and purchase of greeting is not the same as cash price as well only difference regards credit cheaper while the more expensive credit.

\section{CONCLUSION}

Credit is the right to receive payment or obligation to make the payments and the obligation to make payment on demand, or pda time to come, because the delivery of the goods now. Among the forms of commerce were permitted shari'ah is by way of greeting, which ordered the goods with payment in advance (cash). This transaction is the opposite of a credit transaction. When explaining the law of this transaction, the Prophet sallallaahu 'alaihi wa sallam did not require that the price of the goods does not change from a purchase with the delivery of the goods directly. The Prophet sallallaahu 'alaihi wa sallam said only that it means:

\footnotetext{
${ }^{45}$ Jenita, Rustam, dan Deni Marfikuillah, Pinjaman Dana Bergulir Dalam Perspektif Ekonomi Islam, Jurnal Ilmiah Ekonomi dan Bisnis, Vol. 14. No.1, Maret 2017, hlm. 11-30.

46 Ibnu Rusdy, Bidayatul Mujtahid, terj. M. A. Abdurrahman, A. Haris Abdullah (Semarang: CV. Asy-Syifa, 1990), hlm. 32-37.
} 
"Whoever bought by ordering (greetings), he should be ordered in a clear dose and the scales are clear and up to a clear time limit anyway." (Agreed Alaih).

\section{REFERENCE}

Al-Qur'an dan Terjemahannya, Jakarta: Al-Huda, 2005.

Aibak, Kutbuddin, Kajian fiqh kontemporer, Yogyakarta: Teras, 2009.

Anwar Iqbal Qureshi, Islam dan Teori Pembungaan Uang, Jakarta: Tintamas, 1985.

Ahmad Azhar Basjir, Asas-asas Hukum Mu'amalat, Yogyakarta: Perpustakaan Fakultas Hukum UII, 2000.

Ahmkamul Ba'I disusun oleh Syaikh Jarulloh hlm: 58, yang diambil dari http://jacksite.wordpress.com/2007/06/19/hukum-jual-beli-kredit-dalamislam/

Al-Fauzan, Saleh, Fiqh Sehari-Hari, Jakarta: Gema Insani, 2006.

Ahmad Muhyiddin, Etika Bisnis Perbankan, Yogyakarta: CV Mulia Sari, 1994.

Abdullah, M. Faisal, Managemen Perbankan, Teknik Analisis Kinerja Keuangan Bank, Malang: UMM press, 2003.

Abu Umar Faruq Ahmad dan M. Kabir Hassan, Riba And Islamic Banking, Journal of Islamic Economics, Banking and Finance, Vol.1, No.1 tahun 2007.

Antonio, Muhamad Safi'i, Bank Syariah Dari Teori ke Praktek, Jakarta: Gema Insani Press, 2001.

Ahmad Gozali, Serba-Serbi Kredit Syariah: Jangan Ada Bunga Diantara Kita, Jakarta: PT. Elex Media Koputindo, 2005.

ASTROM, Z. Hafsa ORHAN, Credit-Related Practices of Islamic Banks in Comparison with Theory: Case Study of Turkey, International Journal of Islamic Economics and Finance Studies, 2015, Year:1, Volume:1, Number: 2.

Faridah Najuna Mismana, Ishaq Bhatti, Weifang Lou, Syamsyul Samsudin, Nor Hadaliza Abd Rahman, Islamic Banks Credit Risk: A Panel study, Procedia Economics and Finance, Vol. 31. Issue. 1. 2015.

Gamal, Merza, Aktivitas Ekonomi Syari'ah, Pekanbaru: UNRI Press, 2004. 
Ibnu Rusdy, Bidayatul Mujtahid, terj. M. A. Abdurrahman, A. Haris Abdullah Semarang: CV. Asy-Syifa, 1990, Jilid: III.

HR. At-Tirmizi, Sunan Tirmizi, (Semarang: Toha Putra, tth), Nomor Hadis 1331.

HR. Abu Dawud 3461, Hakim 2/45 dengan sanad hasan.

HR. Bukhori 2241, Muslim 1604

Hendi Suhendi, Fiqh Muamalah Jakarta: Rajawali, 2010.

Hamed, Idris Yahaya Adamu, Ahmad Khilmy bin Abdul Rahim, Abu Bakar, Access to Credits and Indebtedness: Islamic Perspective, International Journal of Accounting, Finance and Risk Management, 2016; 1(1).

Hassan, Abu Umar Faruq Ahmad dan M. Kabir, Riba And Islamic Banking, Journal of Islamic Economics, Banking and Finance, Vol.1, No.1 tahun 2007.

Hasan, Zubair. Credit creation and control: an unresolved issue in Islamic banking, International Journal of Islamic and Middle Eastern Finance and Management, Vol. 1. Iss 1, 2008.

Hazniel Harun, Hukum Perjanjian Kredit, Yogyakarta: Tritura, 1989.

Ibnu Abi Syaibah di dalam "Al-Mushannaf (VI/120/502)", Abu Daud dari Ibnu Abi Syaibah (no. 3461),

Imam Mustofa, Fiqh Muamalah kontemporer, Jakarta: Rajawali pers, 2016.

Ibrahim, Azharsyah, Kartu Kredit dalam Hukum Syariah: Kajian terhadap Akad dan Persyaratannya, Jurnal al-Mu'ashirah, Vol. 7, No. 1, 2010.

Kante, Aboubacar Salihou, Credit Cards From The Islamic Legal Perspective (Special Reference To Malaysia), A Thesis Submitted In Partial Fulfilment Of The Requirement For Degree Of Master Of Comparative Laws Ahmad Ibrahim Kulliyyah Of Laws International Islamic University Malaysia, April 2005.

Kuran, Timur. Islamic Economics and the Islamic Subeconomy, Journal of Economic Perspectives, American Economic Association, Volume 9, Number 4, Fall 1995.

Lihat Fatwa Lajnah Daimah 13/154, http://adh-dhuhaa-bjacks.blogspot.com/. 
Lihat Badai'ush Shona'I 5/18, yang diambil dari http://jacksite.wordpress.com /2018 /04/10/hukum-jual-beli-kredit-dalam-islam/

Lihat Hasyiyah Az Zarqoni 3/165, diambil melalui http://adh-dhuhaabjacks.blogspot. com/.

Lihat Al Majmu An Nawawi 13/16, diambil melalui http://adh-dhuhaa-bjacks. blogspot.com/.

M. Ali Hasan, Masail Fiqhiyah: Zakat. Pajak, Asuransi dan Lembaga Keuangan. Jakarta: PT Raja Grafindo Persada, 2003.

Mustofa, Mark Up, Bai Bi Tsaman Ajil Dan Kredit Menurut Manajeman Keuangan Islam, Jurnal Al- Ulum Volume. 10, Nomor 1, Juni 2010.

Murroh Nasution, Adanan, Jual Beli Kredit Ditinjau Dari Persefektif Hukum Islam, Jurnal Yurisprudentia Volume 2 Nomor 2 Desember 2016.

Miftah Idris, Perjanjian Kredit Perbankan Konvensional dan Akad Pembiayaan Perbankan Syariah: Suatu Tinjauan Deskriptif Dalam Hukum Di Indonesia, Jurnal Komunikasi Hukum Universitas Pendidikan Ganesha Singaraja, Volume 1 Nomor 1 Pebruari 2015.

Marfikuillah, Jenita, Rustam, dan Deni, Pinjaman Dana Bergulir Dalam Perspektif Ekonomi Islam, Jurnal Ilmiah Ekonomi dan Bisnis, Vol. 14. No.1, Maret 2017.

Muchdarsyah Sinungan, Dasar-dasar dan Tehnik Managemen Kredit, cet. 7 Jakarta: Bina Aksara, 2003.

Muslehuddin, Muhammad. Sistem Perbankan Dalam Islam, (Jakarta: PT Rineka Cipta, 2004) cet ke-3.

Majmu' Fatawa 19/449, diambil melalui http://adh-dhuhaa-bjacks.blogspot.com/.

Malayu S.P Hasibuan, “Dasar-Dasar Perbankkan”, Jakarta: Bumi Aksara, 2004.

Machmud, Amir, Dkk, Bank Syariah Teori, Kebijakan, Dan Studi Empiris Di Indonesia, Bandung: PT Glora Aksara Pratama, 2010.

Nasution, Adanan Murroh, Jual Beli Kredit Ditinjau Dari Persefektif Hukum Islam, Jurnal Yurisprudentia Volume 2 Nomor 2 Desember 2016.

Qureshi, Anwar Iqbal, Islam dan Teori Pembungaan Uang, Jakarta: Tintamas, 1985. 
O.P. Simorangkir, Pengantar Lembaga Keuangan Bank Dan Non Bank, Cet. II Bogor: Ghalia, 2004.

Risanda Alirastra Budiantoro, Riesanda Najmi Sasmita, Tika Widiastuti, Sistem Ekonomi (Islam) dan Pelarangan Riba dalam Perspektif Historis, Jurnal Ilmiah Ekonomi Islam, Vol. 4, No. 01, 2018

Rachman F dan Maya F. Manajemen Perkreditan Bank Umum: Teori, Masalah Kebijakan dan Aplikasinya, Bandung: Alfabeta, 2013.

S.P Hasibuan, Malayu, “Dasar-Dasar Perbankkan”, Bumi Aksara:Jakarta, 2004

Sahruwardi K Lubis, Hukum Ekonomi Islam, Jakarta: Sinar Grafika, 2000.

Saleh Al-Fauzan, Fiqh Sehari-Hari, Jakarta: Gema Insani, 2006.

Supriyono, "Buku Pintar Perbankan”, CV. Andi Offset: Yogyakarta, 2011

Suyatno, Thomas, dkk, "Dasar-dasar perkreditan”, PT.Gramedia Pustaka Utama: Jakarta, 2007

Syarah Majalah al-Ahkam, no 157, vol III/110, Majallah asy-Syari'ah wad Dirasah Al-Islamiyah, Fak Syari'ah, Kuwait University, edisi VII, Sya'ban 1407, hlm. 140, Al-Maurid, hal. 354, Lisanul 'Arab, vol VII/377-378, melalui artikel di situs Eramuslim.com.

Thomas Suyatno, dkk, "Dasar-dasar perkreditan", Jakarta: PT.Gramedia Pustaka Utama, 2007.

Tricahyadinata, Andi Nursyahriana, Michael Hadjat, dan Irsan, Analisis Faktor Penyebab Terjadinya Kredit Macet, Jurnal FORUM EKONOMI Volume 19, No. 12017.

Uci Fitriani, Makmur, Andi Afrizal, Pengaruh Sistem Penjualan Kredit Di Pt. Surya Putera Sumatera Raya Ii Pasir Putih Pasir Pengaraian Terhadap Penarikan Sepeda Motor Yamaha, jurnal Prodi Manajemen, Fakultas Ekonomi, Universitas Pasir Pengaraian.

Yonas Perwiratama, Sistem Jual-Beli Kredit Motor Di UD Sabar Motor Ditinjau Menurut Hukum Islam, (Fakultas Hukum Dan Fakultas Agama Islam, Universitas Muhammadiyah Surakarta, 2010.

Yusuf, Daud A. Mustafa, Hashir A. Abdulsalam and Jibrail B. Islamic Economics and the Relevance of Al-Qawa id Al-Fiqhiyyah, Jurnal SAGE Open, Vol.1. Issue.1, October-December 2016. 
Z. Hafsa Orhan Astrom, Credit-Related Practices of Islamic Banks in Comparison with Theory: Case Study of Turkey, International Journal of Islamic Economics and Finance Studies, 2015, Year:1, Volume:1, Number: 2. 